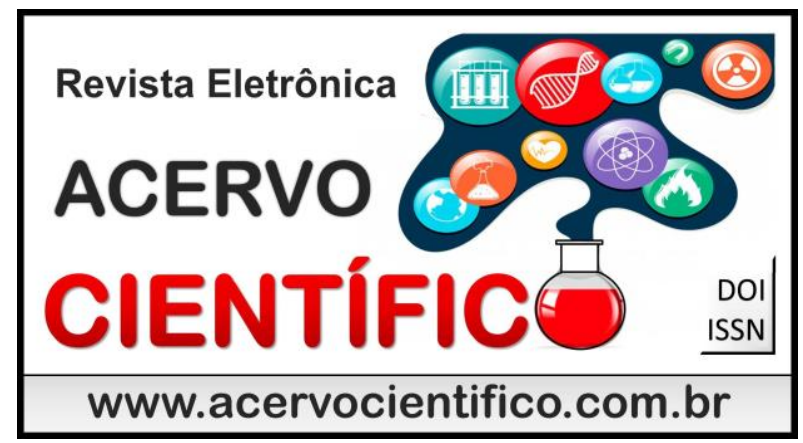

ORIGINAL

Recebido em: 12/2018

Aceito em: 12/2018

Publicado em: 3/2019

\title{
NATURAL SHAMPOO USING NANOBIOTECHNOLOGICAL SUPPLY OF CHLORELLA PYRENOIDOSA
}

\author{
Shampoo natural usando insumo nanobiotecnológico de Chlorella pyrenoidosa \\ Champú natural con aporte nanobiotecnológico de Chorella pyrenoidosa
}

Fabíola Ornellas de Araújo ${ }^{1,2 \star}$, Reinaldo Giudici², João José Martins Simões de Sousa²

\begin{abstract}
The use of cosmetic formulations that preserve the environment and are more biocompatible with human organisms is indispensable. And as there is the growing demand on the part of consumers, who are increasingly demanding to acquire more interesting cosmetic formulations, so that they can solve problems present in the capillary wire, such as, dryness, absence of brightness, presence of oiliness, among other aspects. Consumers want to direct the existing benefits in beauty salons, and TV commercials, among other means of disseminating knowledge, into their homes. These are looking to associate the cost of the finished cosmetic product with the benefit that this brings the skin. In this research we used the continuation of the studies of the scientists Araújo, Giudici and Sousa ${ }^{a}$ and b, in 2018, in the development of a nanobiotechnological input of microalgae, Chlorella pyrenoidosa, which was registered in the USP-2018 patent. Thus, in this research we analyzed a cosmetic formulation, shampoo, in which the nanobiotechnological supply of this microalgae was used.
\end{abstract}

Keywords: Chlorella pyrenoidosa. Araújo, Giudici and Sousaa and b, 2018. Shampoo.

Resumo: $O$ uso de formulações cosméticas que preservam o meio ambiente e são mais biocompatíves com o organismos humano é imprescindível. E como há a crescente demanda por parte dos consumidores, os quais estão cada vez mais exigentes por adquirir formulações cosméticas mais interessantes, para que estas possam solucionar problemas presentes no fio capilar, tais como, ressecamento, ausência de brilho, presença de oleosidade, entre outros aspectos. Os consumidores querem direcionar os benefícios existentes em salões de beleza, e nos comerciais da tevê, entre outros meios de divulgação de conhecimentos, para dentro de seus lares. Estes estão procurando associar o custo do produto cosmético acabado com o benefício que este trás a pele. Nesta pesquisa foi utilizada a continuação dos estudos dos cientistas Araújo, Giudici e Sousa ${ }^{\mathrm{e}}$ b , em 2018, no desenvolvimento de um insumo nanobiotecnológico da microalga, Chlorella pyrenoidosa, o qual foi registrado na patente USP-2018. Sendo assim, nesta pesquisa foi analisada uma formulação cosmética, shampoo, na qual foi empregada o insumo nanobiotecnológico desta microalga.

Palavras-chave: Chlorella pyrenoidosa. Araújo, Giudici e Sousa a b, 2018. Shampoo.

${ }^{1}$ Department of Chemical Engineering, University of São Paulo, Av. Lineu Prestes 580, University City, 05508-090 São Paulo (SP), Brazil. *Corresponding author: ornellasfabiola@gmail.com

2 Faculty of Pharmacy, University of Coimbra, Pólo das Ciências da Saúde, Azinhaga de Santa Comba, 3000-548 Coimbra, Portugal.

Financial support from CNPq (Process of postdoctoral fellowship: 167568/ 2017-5). 
Resumen: El uso de formulaciones cosméticas que preservan el medio ambiente y son más biocompatibles con los organismos humanos es indispensable. Y como existe la creciente demanda por parte de los consumidores, cada vez más exigentes en adquirir formulaciones cosméticas más interesantes, para que puedan resolver los problemas presentes en el alambre capilar, como la sequedad, la ausencia de brillo, presencia de oleosidad, entre otros aspectos. Los consumidores quieren dirigir los beneficios existentes en los salones de belleza, y los comerciales de televisión, entre otros medios de difundir el conocimiento, en sus hogares. Estos están buscando asociar el costo del producto cosmético terminado con el beneficio que esto trae la piel. En esta investigación se utilizó la continuación de los estudios de los científicos Araújo, Giudici y Sousa ${ }^{\mathrm{y}}$ b, en 2018, en el desarrollo de una aportación Nanobiotecnológica de microalgas, Chlorella pyrenoidosa, que se registró en la patente USP-2018. Así, en esta investigación analizamos una formulación cosmética, champú, en la que se utilizó la aportación nanobiotecnológica de estas microalgas.

Palabras clave: Chlorella pyrenoidosa. Araújo, Giudici y Sousa a y , 2018, Champú.

\section{INTRODUTION}

The growing demand of the vanity industry and skin care, to develop more sophisticated and more renewable cosmetic products for the human being is in increasing progress with different marketing strategies. This is why it is important to innovate cosmetic products so that the consumer can obtain a cosmetic with quality, efficiency and efficacy protecting and preserving the functions of the skin, of the capillary wire (VERMA et al., 2003; ARAÚJO et al., 2015)

ABIHPEC (Brazilian Association of the Personal hygiene industry, perfumery and Cosmetics) (2006) reported that Brazil occupies the fourth position, after the United States, Japan and France, in the first, second, and third, respectively, between the ten Countries that consume the most cosmetics in the world. Garcia (2005) reported that major centers involving the development of new technologies in the cosmetics area are found in the United States and Europe. Therefore, researches will be more requested in several industrial areas, especially in this research.

According to the FAO (Food and Agriculture Organization of United Nations) (1997) The controlled cultivation of these aquatic organisms (algae), carried out by man, is a growing industry with great projection worldwide and this represents one of the activities of Important food production for the near future. And the same organ evaluated, in 2003, the frequent use of the algal extracts describing them in lists of ingredients present in the cosmetics packaging, mainly in pharmaceutical formulations, such as creams and/or lotions, for the face, hands, and body.

Other algal inputs used by man are designated as Ficocolloids (Alginate, Carragenan and/or agar). These, which are extracted from the algae wall, are used as raw materials of these formulations (FAO, 1987; JENSEN, 1998; KASS, 1998). These inputs have chemical characteristics, with applications such as stabilizers of suspensions and emulsifiers, gelling, thickeners, and also present solubility in water (RENN, 1997).

Thus, the demand for consuming biodegradable, natural and sustainable products that preserve the environment is paramount. In this context, the development of sustainable and technological cosmetics, with natural components from Microalgal extract, associated with biotechnology, aiming at the lowest possible environmental impact is indispensable. With this, the development of new proposals for cosmetics, with natural components from, for example, Microalgal extract associated with nanotechnology, aiming at the lowest possible environmental impact is indispensable, due to the consumer market Of beauty being ever more growing in the world.

The use of cosmetic formulations that preserve the environment and are more biocompatible with the human organism is fundamental. And as there is the growing demand on the part of consumers, who are increasingly demanding to acquire more interesting cosmetic formulations, so that they can solve problems present in the capillary wire, such as, dryness (capillary wire dehydrated), absence of gloss (capillary wire with matte staining), presence of oiliness (capillary wire with heavy aspect, without malleability in the wires), 
among other aspects. In this way, consumers want to direct the existing benefits in beauty salons, and in TV commercials, among other means of disseminating knowledge, into their homes. These are looking to associate the cost of the finished cosmetic product with the benefit that this brings the skin.

The proposal developed in this research was a finished nanotechnological cosmetic product, designating as nanobiotechnological inputs, which were registered in the USP -2018 patent, which may include several consumers (young, adult, elderly and/or even children). This input used in the shampoo may cause the improvement of existing cosmetics on the market, making them more effective at the time of application on the capillary wire, in addition to that, smart consumers are looking to acquire more products Biodegradable, natural and/or sustainable that can guarantee the preservation of the environment.

Thus, it is in this context that a relevant contribution to research has been proposed, taking advantage of all the possibilities that nanobiotechnology could provide to these sustainable products, in the area of cosmetics for human beings, benefiting them.

The use of biotechnological techniques (discontinuous and/or discontinuous feeding processes) and the achievement of new more sophisticated Microalgal products may influence the development of products Finished cosmetics (formulations) more sophisticated, for example, in order to care for the skin, of the capillary wire (ARAÚJO, GIUDICI \& SOUSA, 2019a and b).

With this, the technology considered "green ", associated with sustainable development, which uses biotechnological processes (raw materials from plants, microalgae and macroalgae) and at the same time enjoy the benefits of nanotechnology (through nanostructures) with viable costs can enrich the science of nanobiotechnology.

Therefore, it can provide consumers with benefits for the hair, skin, moisturizing, rejuvenating and even restructure it, and also, this patented input (USP-2018) can be used in food, since it is nontoxic, And tastes appreciable to the palate, among other employabilities.

With this, increasing the awareness of society for the use of natural products, based on plants and/or microbiotas would diminish the harmful effects, such as the use of synthetic dyes, in foods, medicines and cosmetics (KULSHRESHTHA \& SINGH, 2013).

In conclusion, making use of new pharmaceutical inputs biocompatible with the human organism, which bring benefits, for example, to the capillary wire and the skin, are very important. The input developed in the USP-2018 patent, which was applied in this research was a promising alternative not only in the cosmetic area, but in other areas, as described in the USP-2018 patent.

\section{MATERIALS AND METHOD}

PREPARATION OF THE INOCULUM/ MICROALGAL MATERIAL / DETERMINATION OF CELLULAR CONCENTRATION/ DETERMINATION OF PH/ BIOMASS EVALUATION OBTAINED/ BIOMASS EVALUATION OBTAINED/ DETERMINATION OF THE PROTEIN CONTENT OF BIOMASS $c$. pyrenoidosal DETERMINATION OF THE LIPID CONTENT OF BIOMASS C. pyrenoidosal DETERMINATION OF ASH CONTENT FOR C. PYRENOIDOSA/ DETERMINATION OF TOTAL CARBOHYDRATE CONTENT FOR $C$. pyrenoidosa/ IDENTIFICATION AND QUANTIFICATION OF FATTY ACID COMPOSITION THROUGH GAS CHROMATOGRAPHY/ IDENTIFICATION AND QUANTIFICATION OF COMPOSITION OF FATTY ACIDS, THROUGH GAS CHROMATOGRAPHY COUPLED TO MASS SPECTROMETRY

The explanations of these items cited above were described by the scientists Araújo, Giudici and Sousa, in $2018^{a}$ and $b$.

In the present study was used the microalgae strain Chlorella pyrenoidosa (Chlorella sorokiniana) (UTEX 1663) from the UTEX microalgae (The Culture Collection of Algae of the University of Texas at Austin U.S.A.) (UTEX, 2011; Araújo, Giudici and Sousa, in 2018 and b). 


\section{SUPPLY NANOBITECNOLOGICAL}

The instruments used, the methodology, as well as the analyses for the development of pharmaceutical nanobiotechnological supplies developed in the present invention are described in the patent of USP, 2018. And from it, an adaptation was performed to develop nannobiotechnological supplies. With this, the highest concentration (10\%) was used, in which the concentrations of $1.50 \%, 3 \%$ and $4.5 \%$ were removed, and these were used as pharmaceutical supplies in the formulation of the shampoo described in this article.

In this patent, some parameters were evaluated, such as average nanoparticle size and mean zeta potential.

\section{ANALYTICAL TECHNIQUES TO SHAMPOO ANALYSIS AND Natural Shampoo (adapted}

\section{ARAÚJO et al., 2015)}

Shampoo triplicates were analyzed (Table 1) to content of supply nanobiotechnological, $1.50 \%, 3 \%$ and $4.5 \%$.

It analyzed the following physico-chemical properties:

i) $\mathrm{pH}$ between $5.0-7.0$, preferably shampoos should have a slightly acidic $\mathrm{pH}$;

ii) viscosity can be determined by a rotary viscometer such as Brookfield and Ford viscosity cup. It is recommended that the viscosity of the shampoo is at least $2,000 \mathrm{cps}$, and most commercial shampoos have viscosity of 2,000 to $5,000 \mathrm{cps}$;

iii) density, can be determined in aluminum or stainless steel pycnometer, generally comprises from the 1.010 to $1.020 \mathrm{~g} / \mathrm{ml}$;

iv) the foam persistence time, one should add $40 \mathrm{ml}$ of distilled water in a graduated cylinder of $100 \mathrm{~mL}$, then add $1 \mathrm{~g}$ of shampoo sample soon after - the graduated cylinder should be covered with the palm of the hand and shake strongly in the vertical direction until the foam fills the entire the graduated cylinder.

Then cap the graduated cylinder with a plastic film, leaving it in protected from light, and measuring time until the total disappearance of the foam, i.e., foam persisting time; among other (FERREIRA, 2008).

The development of a natural shampoo formulation (Table 1). The method of preparation: dissolve the dye in water and then dispense and hydrate the xanthan gum to the complete formation of a gel. Add the components of phase $\mathrm{B}$ and homogenize. Add phase $\mathrm{C}$ and homogenize. Adjust the $\mathrm{pH}$ with citric acid.

There is concern and awareness by consumers to demand quality and origin of the constituents of cosmetic formulations. Many look for more natural products, which use in their plant extracts formulations, vegetable oils, in short, raw materials exploited with sustainability of nature, the most varied (diverse) kingdoms, vegetables, minerals, protists, among others. This cosmetic formulation showed little foam, which could be better accepted, for children, thus decrease the chance of contact of the foam, for being slippery, with eyes thus reducing eye irritation (MORELLI \& WESTON, 1987; KLEIN, 2004; FERREIRA, 2008; ARAÚJO et al., 2015).

Thus, the substances responsible for foam appearance are called surfactants, the most widely used by the industrialized shampoos are usually sodium lauryl sulfate, lauryl ether sodium sulfate, and derivatives of fatty coconut acids, such as this survey, sodium cocoyl glutamate, decyl glucoside (LEIDREITER, GRUNING \& KASEBORN, 1997; IMOKAWA, 1997; ARAÚJO et al., 2015).

Although the latter can cause less irritability, there are reports in the literature of the occurrence of late human hypersensitivity using them in cosmetic formulations, however there are also reports that these may have a low degree of oral irritation, skin and eye (GOOSSENS A. \& MERCKX, 1997; VILAPLANA, MASCARO \& TRULLAS, 1992; KORTING et al., 1992; FOWLER, 1998; BARANY, LINDBERG \& LODEN, 1999; MOWAD, 2001; SANTUCCI, CANNISTRACI \& LESNONI, 2003; ARAÚJO et al., 2015). 
Table 1. Natural Shampoo composition (adapted from RIBEIRO, 2010; adapted ARAÚJO et al., 2015).

\section{Natural Shampoo}

\section{Phase A}

Dye $0.01 \%$ (color optional)

Xanthan Gum 0.20\%

Water qs to $100 \mathrm{~mL}$

\section{Phase B}

Supply nanobiotechnological $1.50 \%, 3 \%$ and $4.5 \%$ *

Biosaccharide gum-1 $2.00 \%$

Organic extract (rice ${ }^{* *}$, lemon, lotus, apple ${ }^{* *}$, kiwi, grape, ginger, orange, bamboo ${ }^{* *}$, among others) $0.51 \%{ }^{* *}$

\section{Phase C}

Natural fragrance $0.25 \%$ (optional)

Tea tree oil $0.15 \%$

Brazil nuts oil $0.15 \%$

Copaiba oil $0.20 \%$

Cocoyl glutamate sodium $4.5 \%$

Decyl glucoside $18 \%$

\section{Phase D}

Citric acid (adjust the $\mathrm{pH}) \mathrm{pH}$ 5.5-7.0

*developed in this research.

${ }^{* *}$ used in this shampoo (blends of organic extracts: rice $(0.17 \%)$; apple $(0.17 \%)$ and bamboo $\left.(0.17 \%)\right)$.

\section{RESULTS AND DISCUSSION}

Through analysis of variance (ANOVA one-way) the Tukey and Fischer tests were applied with a 95\% confidence interval for each sample and was carried out tests in triplicate natural shampoo (Table 2), which showed significant differences $(p<0.05)$ between them for the parameters analyzed here: viscosity, density and the foam persistence time. There was no significant difference for $\mathrm{pH},(\mathrm{p}>0.05)$ (ARAÚJO et al., 2015).

The viscosity values for the shampoo with $4.5 \%$ supply nanobiotechnological (Table 2 ) corroborated with commercial shampoo viscosity values described by Ferreira (2008) and Araújo et al., 2015. This pharmaceutical formulation is safe for use, as it is completely non-toxic, for human use (USP, 2018).

In Vitro tests, in vivo and ex vivo were not analyzed in this shampoo were only evaluated some physicchemical parameters, cited below.

And the cultivation was carried out in closed shaker, to avoid contamination of microalgal raw material. 
Table 2. The experimental were performed in triplicates, for each shampoo formulation.

\begin{tabular}{lccc}
\hline \multirow{2}{*}{ Experimental } & \multicolumn{3}{c}{ Supply nanobiotechnological C. pyrenoidosa } \\
\cline { 2 - 4 } & $\mathbf{1 . 5 0 \%}$ & $\mathbf{3} \%$ & $\mathbf{4 . 5 0 \%}$ \\
\hline viscosity $(\mathrm{cps})$ & $1,351 \pm 0.04^{A}$ & $1,533 \pm 0.13^{B}$ & $2,235 \pm 0.25^{C}$ \\
density $(\mathrm{g} / \mathrm{mL})$ & $0.035 \pm 0.08^{\mathrm{A}}$ & $0.569 \pm 0.35^{B}$ & $1.543 \pm 0.09^{\mathrm{C}}$ \\
$\mathrm{pH}$ & $6.5 \pm 0.05^{\mathrm{A}}$ & $6.5 \pm 0.03^{\mathrm{A}}$ & $6.5 \pm 0.02^{\mathrm{A}}$ \\
foam persistence time (minutes) & $3 \pm 1.5^{\mathrm{a}}$ & $4 \pm 1.3^{b}$ & $6 \pm 1.8^{\mathrm{C}}$ \\
\hline
\end{tabular}

* Different letters in the same line represent statistically different values.

This article shows the importance of the use of pharmaceutical products (shampoo) with non-toxic pharmaceutical ingredients, which involve personal care and do not harm the environment. There are numerous studies that report environmental contamination and the risk to ecological health (OLKOWSKA et al, 2014; RAMOS et at., 2015, TEO et al, 2015).

In this research was developed a new active pharmaceutical ingredient, biocompatible with the human organism, nontoxic, sustainable for the environment (USP, 2018). The use of this is indicated, in different pharmaceutical formulations, mainly in formulations that ingredients are dispensed through the use of running water, through the bath, because it does not contaminate the environment (soil and groundwater).

\section{CONCLUSION}

The algae obtaining supply nanobiotechnological associated with natural cosmetic formulations, for example, can be a feature that present good acceptance by consumers because it is environmentally friendly. Depending on the species of algae studied, it will be appreciated, for example, protein compositions and/or different lipids. These can be used in various purposes of cosmetic formulations, as was the case of this research. A better understanding of secondary metabolites, designated ecological chemistry, called the "green", can allow us to discover and find these valuable compounds for use not only in cosmetics, but also for use in medicines, and/or several industrial purposes, improving the life of human beings as a whole. The search for more sustainable alternatives in obtaining for more renewable raw materials is part of the awareness of the current technological society (ARAÚJO et al., 2015; USP, 2018).

\section{ACKNOWLEDGMENTS}

The authors acknowledge the financial support from CNPq (Process of postdoctoral fellowship: 167568/ 2017-5).

\section{REFERENCES}

1. ABIHPEC. Associaçcão Brasileira da Indústria de Higiene Pessoal, Perfumaria e Cosméticos. Panoroma do Setor: Higiene Pessoal, Perfumaria e Cosméticos. $2006 . \quad$ Available in: www.abihpec.org,br/dadosdomercado panorama setor.php . Accessed in: 03/01/2015.

2. ARAÚJO FO, GIUDICI R, et al. Cultivation of the microalgae Chlorella pyrenoidosa using the processes of Biotechnology. Revista Eletrônica Acervo Científico/ Eletronic Journal Science Collection. 2: e121, 2019. ${ }^{a}$

3. ARAÚJO FO, GIUDICI R, et al. Identification of the lipids of the microalgae Chlorella pyrenoidosa, after obtaining this through use of Biotechnology. Revista Eletrônica Acervo Científico/ Eletronic Journal Science Collection. 3: e122, 2019. ${ }^{\text {b }}$

4. ARAÚJO FO., CARVALHO JCM, VELASCO MVR., et al. Natural Shampoo using resources from aquatic environments. HOUSEHOLD AND PERSONAL CARE TODAY (TESTO STAMPATO). 10: 46-50, 2015. 
5. BARANY E, LINDBERG M, LODEN M. Biophysical characterization of skin damage and recovery after exposure to different surfactants. Contact Dermatitis. 40: 98-103. 1999.

6. FAO. El Estado Mundial de la Pesca y la Acuicultura, 1996. Food and Agricultural Organization of the United Nations. Roma, Italia. 1997.

7. FAO. Production and utilization of products from comercial seaweeds. Food and Agricultural Organization of the United Nations. Roma, Itália. 288p. 1987.

8. FERREIRA AO. Guia Prático da Farmácia Magistral. $3^{a}$ ed.. Pharmabooks. São Paulo. 2008. 409p.

9. FOWLER JF JR. Allergy to cocamide DEA. Am. J. Contact. Dermat. 9: 40-1. 1998.

10. GARCIA R. Internacionalização comercial e produtiva na indústria de cosméticos: desafios competitivos para empresas brasileiras. Revista Produção. 15: 158-171. 2005.

11. GOOSSENS A, MERCKX L. Contact allergy to cosmetics. (Paris). Allerg Immunol. 29: 300-303. 1997.

12. IMOKAWA G. Surfactant mildness. In: RIEGER, M.M., RHEIN, L.D., MARCEL, D. (eds). Surfactants in Cometics, Surfactant Science Series, New York, 1997. 427p.

13. JENSEN A. The seaweed resources of Norway. In: CRITCHLEY, A.T. and OHNO, M. (eds). Seaweed resources of the world. Japan International Cooperation Agency, Yokosuka, Japan. 200-209p. 1998.

14. KASS R. The seaweed resources of France. In: CRITCHLEY, A.T. and OHNO, M. (eds). Seaweed resources of the world. Japan International Cooperation Agency, Yokosuka, Japan. 233-244p. 1998.

15. KLEIN K. Formulação de Shampoo: Os fundamentos. Cosmetic \& Toiletries (Edição em Português). $16: 50-53$. 2004.

16. KORTING HC, PARSCH EM, ENDERS F, et al. Allergic contact dermatitis to cocamidopropyl betaine in shampoo. J Am Acad Dermatol. 27:1013-5. 1992.

17. KULSHRESHTHA J, SINGH GP. Evaluation of various inorganic media for growth and biopigments of Dunaliella salina. Int. J. Pharm. Bio. Sci. 4: (B) 1083 - 1089. 2013.

18. LEIDREITER HI, GRUNING B, KASEBORN D. Amphoteric surfactants: processing, product composition and properties. Int. J. Cosmet. Sci. 19:239-253. 1997.

19. MORELLI JG, WESTON WL. Soaps and shampoos in pediatric practice. Pediatrics. 80: 634-637. 1987.

20. MOWAD CM. Cocamidopropyl betaine allergy. Am. J. Contact. Dermat. 12: 223-4. 2001.

21. OLKOWSKA E., POLKOWSKA Z., RUMAN M., NAMIESNIK J.. Similar concentration of surfactants in rural and urban areas. Environ Chem Lett. 13:97-104. 2014.

22. RAMOS S., HOMEM V., ALVES A., SANTOS L. Advances in analytical methods and occurrence of organic UVfilters in the environment-a review. Sci Total Environ. 526:278-311. 2015.

23. RENN D. Biotechnology and the red seaweed polysaccharide industry: status, needs and prospects. Trends in Biotech. 15: 9-14. 1997.

24. RIBEIRO CJ. Cosmetologia Aplicada a Dermoestética. $2^{a}$ edição. Pharmabooks. 2010. 439 p.

25. SANTUCCI B, CANNISTRACI C, LESNONI I. Cutaneous response to irritants. Contact Dermatitis. 48: 69-73. 2003.

26. TEO T.L.L., COLEMAN H.M., KHAN, S.J.. Chemical contaminants in swimming pools: occurrence, implications and control. Environ Int. 76:16-31. 2015.

27. UNIVERSIDADE DE SÃO PAULO (USP-SP). ARAÚJO FO, GIUDICI R. "Processo para obtenção de insumos nanobiotecnológicos, formulação farmacêutica e usos da mesma". BR102017024578-0. 07 de agosto de 2018. Revista da Propriedade Industrial - RPI №. 2483, p. 306. 2018.

28. UTEX. The Culture Collection of Algae (1663; 2011). Available in: http://web.biosci.utexas.edu/utex/default.aspx/. Accessed in: 03/ 23/ 2011.

29. VERMA DD, VERMA S, BLUME G, FAHR A. Particle size of liposomes influences dermal delivery of substances into skin. International Journal of Pharmaceutics. 258: 141-151. 2003.

30. VILAPLANA J, MASCARO JM, TRULLAS C. Human irritant response to different qualities and concentrations of cocoamidopropylbe taines: a possible model of paradoxical irritant response. Contact Dermatitis. 26: 289-94. 1992. 